\title{
Díky muzeu mohou moderním dějinám rozumět i malé děti
}

\author{
Zdeňka Kulhavá, Barbora Hoduláková
}

\section{Thanks to the Museum, Even Young Children Can Understand Modern History}

Abstract: The joint exhibition of National Museum of Czech Republic and Slovak National Museum dedicated to commemorate the 100th anniversary of the creation of Czechoslovakia was an opportunity to create a cooperative international educational program for the children of school age to effectively learn about modern history.

Keywords: museum education, Czechoslovakia, modern history, National museum, children

Baví se dva kluci:

K1: „Fakt nemůžu, zitra je svátek, a tak musím s matinkou a fotříkem za babkou."

K2: „Svátek? Jakej svátek?"

K1: "Nějakýho Cyrila a Metoděje."

K2: "Joooo, tyhle, tak to jo."

K1: "Nemám páru, kdo to je. Ty je znáš?"

K2: "Tyhle zná každej. Ty přece založili komunistickou stranu, vole, vrat' se na základku. “1

Takto vypadal náhodou zaslechnutý rozhovor dvou teenagerů. A nikdo se nepozastaví nad tím, že takových př́kladů jsou desítky. Stačí jen sledovat zpravodajství $\mathrm{v}$ den kteréhokoli státního svátku, v nichž podnikají reportéŕi mezi veřejností anketu, ve které se ptají osob různého pohlaví, věku, sociálního i ekonomického postavení, zda-li tuší, k jaké události nebo připomínce významné osobnosti se daný svátek váže. Celý národ se pak baví nesmyslnými odpověd’mi, které v reportáži zazní.

Poslední roky se ve vzdělávání na všech stupních výrazně akcentují moderní dějiny. Jejich tematika prostupuje oblast formálního i neformálního vzdělávání, je to časté téma mediálních a politických debat. Přesto se setkáváme stále s velkým procentem lidí, kteří nedisponují bazální znalostí historických faktů a už vůbec si neumí dát věci do souvislostí.

Právě v této oblasti porozumění a pochopení historických událostí mohou být školám a veřejnosti prospěšné pamětové instituce, $v$ našem př́padě muzea, at už svými výstavami nebo doprovodným programem, který k nim připravují.

Národní muzeum (dále NM) realizovalo v letech 2018 a 2019, ve spolupráci se Slovenským národním muzeem (dále SNM), Česko-slovenskou / Slovensko-českou výstavu, která byla nejprve zahájena v dubnu 2018 v Bratislavě a v říjnu téhož roku v Praze. V textu tohoto článku bude pojednáno zejména o české části výstavy. Ta nebyla rozsáhlá jen svým obsahem a počtem vystavených exponátů, ale také doprovodnými aktivitami, které k ní pro veřejnost NM připravilo.

Doprovodný program pro školní mládež byl vzhledem $\mathrm{k}$ tématu výstavy zaměřen zejména na žáky základních a středních škol. Proto bude v tomto článku pojednáno o čtyřech hlavních aktivitách, které byly na tuto skupinu návštěvníků zaměřeny: besedy s pamětníky týkající se vybraných milníků v dějinách Československa; lektorované edukační programy; samoobslužné pracouní listy s metodikami pro pedagogy; projekt 100 let Československa v naší škole. Pro širokou veřejnost byly připraveny samoobslužné interaktioní proky ve výstavě a tištěný průvodce výstavou. Zároveň oddělení vzdělávání a kulturních aktivit připravilo sobotní doprovodný program pro rodiny s dětmi na téma proměny československých státních svátků (17. 11. 2018) a na připomínku dětství v Československu (11. 5. 2019). 


\section{Besedy s pamětníky}

Díky spolupráci s Kontaktním centrem pro oběti nacismu a mezigenerační dialog Živou pamětí, o. p. s. připravilo oddělení vzdělávání a kulturních aktivit $N M \mathrm{k}$ výstavě $\mathrm{s}$ významným výročím tzv. osmičkových roků v roce 2018 pro žáky druhých stupňů základních škol a středních škol, besedy s pamětníky. Setkání proběhlo celkem sedm a zúčastnilo se jich 845 žáků. Na dobu, na níž nemáme již pamětníky nebo témata, $\mathrm{k}$ nimž se nám pamětníky nepodařilo oslovit, jsme využili přednášek. Tématy jednotlivých besed a přednášek byly: Vznik Československé republiky; Mnichovská dohoda a druhá světová válka; prezident Emil Hácha (1938-1945); Únor 1948; Pražské jaro a 21. srpen 1968; 17. listopad 1939; 17. listopad 1989.

Obrovskou výhodou besed s pamětníky je jejich autentičnost. Skutečnost, že danou dobu, o níž vypráví, zažili, je pro děti a mládež fascinující a nemusí se jednat ani o aktéry velkých dějin. Stačí, že jsou ochotni vyprávět, jak danou dobu prožívali, co si o ní mysleli, jak na to nahlíží s dnešní zkušeností apod. Žáci ve většině případů nadšeně naslouchají. Velice se vydařila beseda s paní Helgou Hoškovou, která hovořila o tématu holocaustu a sdílela své životní zkušenosti, kdy coby malá dívka prošla koncentračním táborem Terezín, nebo beseda s biskupem Václavem Malým na téma listopadových událostí roku 1989.

Achilleovou patou besed s pamětníky je jejich věk, fyzická a duševní kondice. Jak se i nám stalo, dvaadevadesátiletého pamětníka zradila pamět i schopnost koncentrace a svůj př́běh, který mi ještě cestou do muzea zaujatě vypravoval $v$ taxíku, již nedokázal sdělit žákům. I přes to, že by se dalo říci, že tato beseda neměla pro žáky význam, to, že si šli s pamětníkem následně pohovořit a podat mu ruku, svědčí o tom, že je jeho vyprávění oslovilo. Nutno ještě upozornit na politováníhodnou skutečnost, která se s touto zkušeností pojí, že ještě před skončením besedy opustili někteří žáci i jejich pedagogický

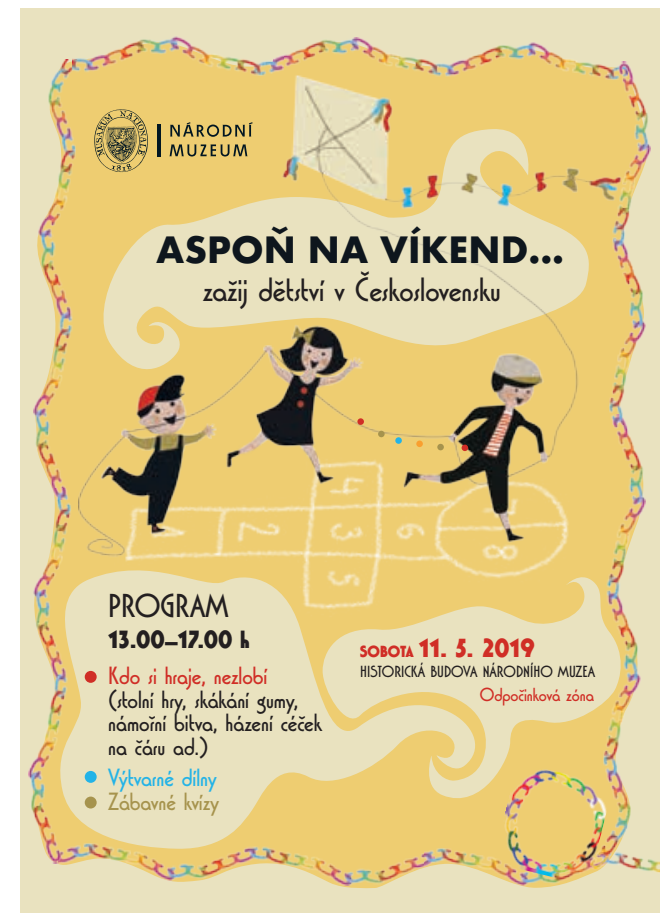

Plakát akce Aspoň na víkend... zažij dětství $v$ Československu, Národní muzeum, 11. 5. 2019

dozor sál. At̃ už se snažíme pochopit, že jsme krátce přesáhli časový rámec besedy, považujeme za neslušné a pro žáky nepř́kladné, nenechat pamětníka domluvit a rušit jej hromadným odchodem.

Aby žáci porozuměli historickému kontextu doby, o níž budou pamětníci vyprávět, připravili jsme pro ně jako součást besed stručný historický úvod. Těchto dvacetiminutových přednášek se zhostili kolegové z Historického muzea NM a jejich externí spolupracovníci. Pokud budeme chtít hodnotit tyto úvody, vnímáme je my i zúčastnění pedagogové velice pozitivně. Avšak záleží na jejich didaktickém zpracování a podání žákům. $V$ některých případech činilo přednášejícím obtíže uvědomit si, pro jakou cílovou skupinu svůj př́spěvek chystají. Svá témata měli výborně zpracovaná, ale na takové odborné úrovni, které žáci mnohokrát nerozuměli a nedokázali si věci adekvátně propojit. Tento fakt lze považovat za výzvu do budoucna, abychom dokázali žákům sdělit potřebné informace jim přiměřenou 


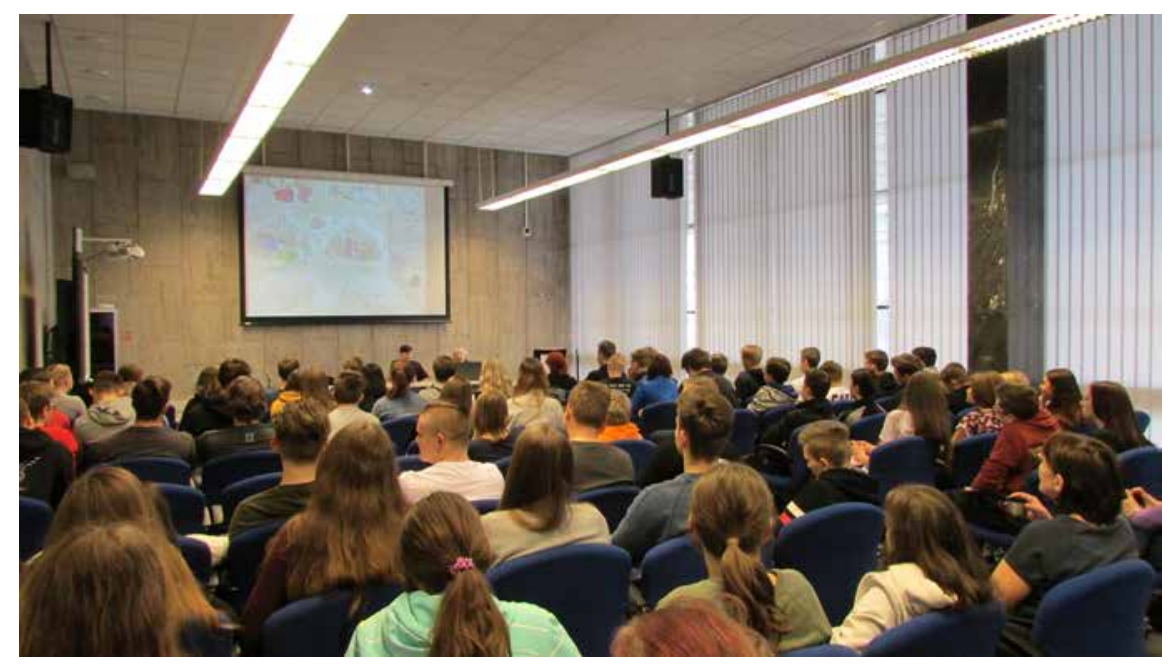

Beseda s paní Helgou Hoškovou, 14. 3. 2018

2 Vzhledem $k$ rozmanitosti Rámcových vzdělávacích programů pro střední odborné školy využíváme vždy jako zdroj výstupů RVP G, ale jsme si vědomi, že je nutné program žákưm středních odborných škol přizpůsobit.

a srozumitelnou formou a mohli zároveň spolupracovat s odbornými pracovníky.

\section{Interaktivní edukační programy pro školy}

Národní muzeum dnes již s naprostou samozřejmostí připravuje $\mathrm{k}$ jednotlivým výstavním projektům edukační programy pro školy všech typů a stupňů. Pracovníci oddělení vzdělávání a kulturních aktivit NM i jejich kolegové na dalších objektech NM přizpůsobují edukační programy schopnostem, znalostem, dovednostem a vzdělávacím potřebám žáků. Nejinak tomu bylo u Česko-slovenské / Slovenskočeské výstavy. Vzhledem k jejímu tematickému záběru jsme se uchýlili, v souladu s Rámcovými vzdělávacími programy pro základní vzdělávání (RVP ZV) a gymnázia (RVP G), ${ }^{2} \mathrm{k}$ interaktivním edukačním programům pro tři věkové kategorie. Žáky 4. a 5. tříd Ž̌, 8. a 9. tříd Ž̌ a SŠ. Každý typ programu se odehrával

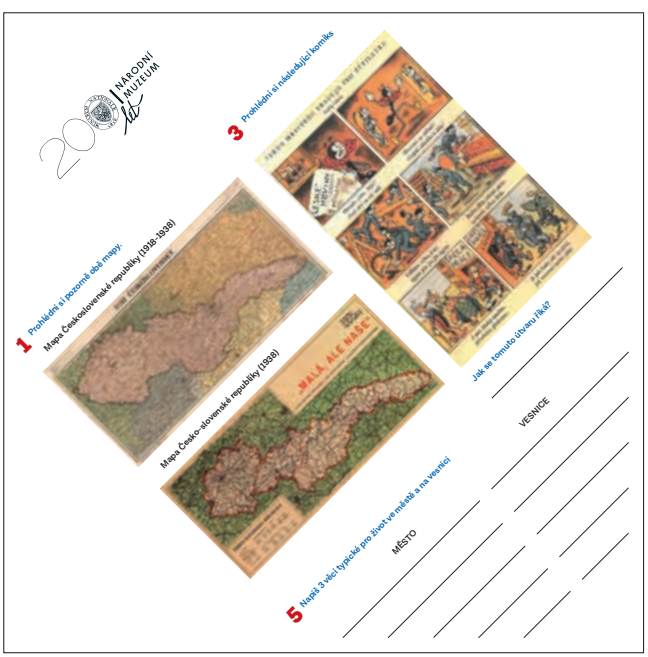

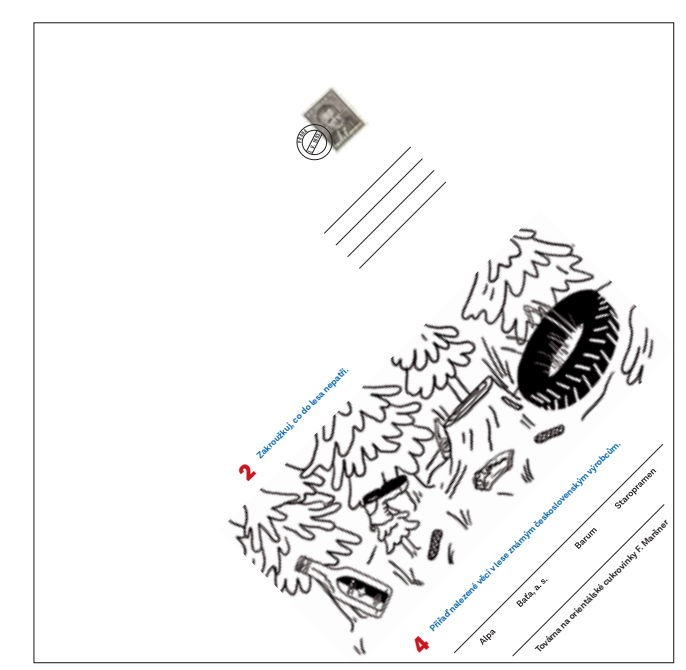

Pracovní list k edukačnímu programu Poznáváme Československo, 2018 (Národní muzeum)

ve výstavě a využíval práci s pracovními listy. Pro nejmladší věkovou kategorii byl připraven vzdělávací program „Poznáváme Československo", pro starší žáky základních škol "Hej, Československo..." a pro střední školy program „Od svobody ke svobodě (1918-1992)“.

Programy napříč věkovým spektrem návštěvníků rozvíjely jejich kritické myšlení. Korespondovaly s výstupy danými příslušnými RVP. Neakcentovaly jen jednotlivé vzdělávací obory, ale také prưřezová témata a podporovaly mezipředmětové vztahy. Cílem edukačních programů bylo ukázat žákům na konkrétních předmětech a př́kladech klíčové mezníky našich dějin a vést je $\mathrm{k}$ porozumění př́ičin, vývoje a následků jednotlivých událostí. Díky tematickému rozdělení výstavy bylo možné ukázat, jak se jedna událost promítla do různých oblastí občanského, politického i duchovního života. Podařilo se nám tak pracovat s prekoncepty žáků, s nimiž na program přicházeli. Bořili jsme je a na základě nových informací jim pomohli vystavět poznatky nové a pochopit vztahy mezi historickými událostmi a rovinami života, do nichž se prolínají. Pracovní listy pro lektorované edukační programy byly graficky zpracovány tak, aby mohly být poskládány do podoby dopisní obálky, jako symbolu jednoho z hlavních komunikačních prostředků 20. století. 

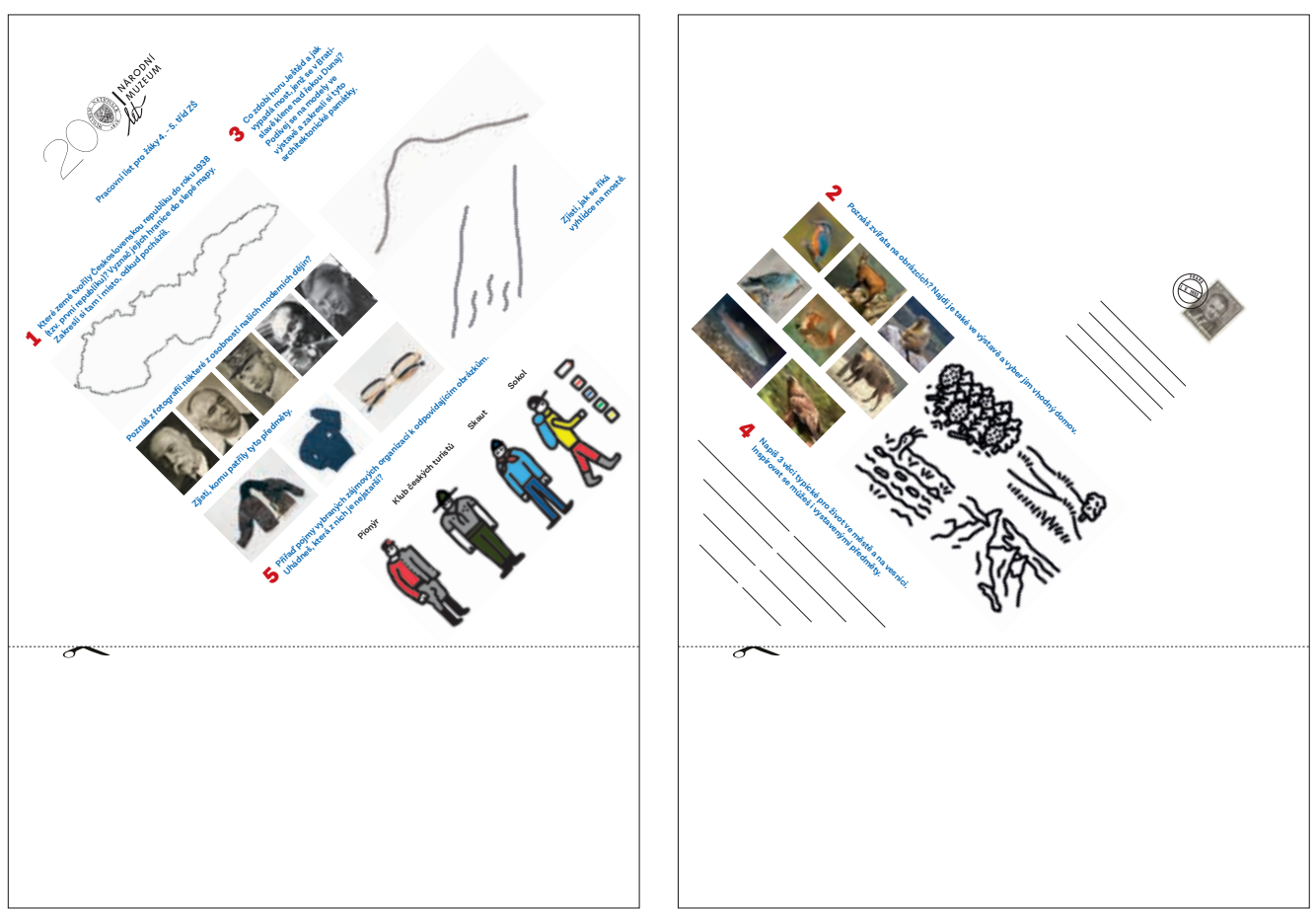

Samoobslužný pracovní list pro žáky 4. a 5. tříd ZŠ, 2018 (Národní muzeum)

$\mathrm{V}$ rámci edukačních programů navštívilo Česko-slovenskou / Slovensko-českou výstavu 223 školních kolektivů základních (162 skupin) a středních škol (61 skupin) s celkovým počtem 4872 žáků. Návštěvnost škol bez lektorovaného programu byla ještě vyšší. Celkem se jednalo o 338 skupin s 12620 žáky. ${ }^{2}$

\section{Samoobslužné pracovní listy pro žáky a metodické listy pro pedagogy}

Protože kapacita edukačních programů absolutně nedostačovala poptávce, připravili pracovníci oddělení vzdělávání a kulturních aktivit NM samoobslužné pracovní listy pro žáky a metodické listy pro učitele, které byly volně ke stažení na webových stránkách NM. Metodické listy mohly být pedagogům prospěšné při př́pravě exkurze a následného plnění jednotlivých úloh v pracovních listech, kdy správné odpovědi vyžadovaly orientaci ve výstavě. Statisticky nemáme zaznamenán údaj, který by kvantitativně vylíčil zájem o práci s těmito materiály, ale díky každodennímu pohybu ve výstavě můžeme tyto pracovní listy hodnotit jako hojně využívané.

Samoobslužné pracovní listy reflektovaly jednotlivé cílové skupiny žáků ZŠ a SŠ, které dle RVP ZV a RVP G měly téma dějin 20. století probírat. Samoobslužné pracovní listy, stejně jako pracovní listy pro lektorované edukační programy, byly graficky zpracovány tak, aby ve výsledku mohly být poskládány do podoby dopisní obálky.

\section{0 let Československa v naší škole}

Projekt 100 let Československa v naší škole byl nejrozsáhlejší a nejnáročnější součástí doprovodného programu pro školy. Jednalo se o mezinárodní projekt s českou a slovenskou pưsobností, jímž jsme oslovili tisíce základních a středních škol v České a Slovenské republice. Jeho realizace probíhala od podzimu 2017 do června 2018, kdy vyvrcholil exkurzí vítězných školních kolektivů z Čech a ze Slovenska do Bratislavy.
2 Kapacita edukačních programů byla limitována výrazným zájmem veřejnosti o výstavu a návštěvní kapacitou Historické budovy a výstavy samotné. Proto v měsících ríjnu až prosinci 2018 probíhaly edukačni programy jen $v$ omezených dopoledních časech trí dny v týdnu. Pokud by edukační programy probihaly každý všední den v celodenním režimu, jak bylo zvykem u ostatních výstav Národního muzea, byla by návštěvnost škol několikanásobně vyšší. To také zdůvodňuje, proč byla návštěvnost školních kolektivu bez lektorovaného programu vyšší než s ním. V roce 2019 byla nabídka edukačních programů $v$ dopoledních časech rozšířena na pět dní v týdnu a každý všední den bylo navíc možné prihlásit se i na tři odpolední časy. Opomenout samozřejmě nelze ani to, že Historická budova Národního muzea byla touto výstavou otevřena po několikaleté rekonstrukci a do 31. 12. 2018 bylo vstupné (včetně edukačních programů) zdarma. 
3 Práci dokončily: Arcibiskupské gymnázium v Kroměřiži; Gymnázium Česká Lípa; Gymnázium Frýdlant; Gymnázium Karla Capka, Dobřišs; Gymnázium Lovosice; Jiráskovo gymnázium, Náchod; Masarykova základní škola, Lubenec; Základní škola Fakultní škola Pedagogické fakulty UK Slovenská, Praha; Základní škola Na Smetance, Praha 2; Střední pedagogická a Střední zdravotnická škola Krnov; Střední škola průmyslová, hotelová a zdravotnická, Uherské Hradiště; Střední škola stavebních řemesel, Brno;

Sunny Canadian International School, Jesenice; Základní škola Zámecká, Litomyšl; Základní škola Opava; Základní škola Veltrusy; Základní škola a Mateřská škola Bílá Třemešná; Základní škola a Mateřská škola Klučenice; Základní škola Bítovská, Praha; Základní škola Kamenice; 22. základní škola Plzeň; Základní škola Teplice; Základní škola Žatec.

4 Cirkevná základná škola Narnia, Pezinok; Gymnázium Jozefa Lettricha, Martin; Gymnázium Matky Alexie, Bratislava; Gymnázium Pezinok; Gymnázium Malacky; Obchodná akadémia, Šurany; Stredná umělecká škola scénického výtvarníctva, Bratislava; Základná škola Mierova, Bratislava; Základná škola s materskou školou Slovenský Grob; Základná škola Dr. J. Dérera, Malacky; Základná škola Sadová, Senica. 5 Z hlediska vzdělanostního stupně bylo 129 respondentů ze základních škol, 25 z Gymnázia Frýdlant a 12 ze Střední odborné pedagogické školy a Střední zdravotnické školy v Krnově.
Cílem projektu bylo přiblížit žákům moderní dějiny Československa a připomenout jim významné okamžiky, které ve 20. století formovaly náš národ a dosud ovlivňují naši kolektivní pamět. Žáci byli prostřednictvím komplexní metodiky vedeni $\mathrm{k}$ navázání mezigeneračních rozhovorů $\mathrm{v}$ rodinách. Současně měli díky rozhovorům získat nejen informace, ale také předměty, které se vztahují $\mathrm{k}$ období Československa a které jim rodiče či známí dovolili použít pro účely školních výstav. Velmi pozitivním důsledkem této aktivity byly případy, kdy zareagovalo široké komunitní prostředí, kdy lidé z řad veřejnosti nabízeli do výstavy své předměty, i když již neměli na školu žádnou vazbu.

Do projektu se zapojilo 20 základních a 7 středních škol z České republiky ${ }^{3}$ a 5 základních a 7 středních škol ze Slovenské republiky. ${ }^{4}$ Z hlediska přihlášených kolektivů se celkem jednalo o 57 kolektivů ze základních a 17 ze středních škol s téměř 1400 žáky. Jak tedy vyplývá, převažovala účast základních škol a následně měla početné zastoupení i víceletá gymnázia. Nezanedbatelnou část soutěžních kolektivů tvořily i střední školy. Nejednalo se jen o gymnázia, ale také o střední odborné školy. Již jejich samotná účast je velmi pozitivním aspektem tohoto projektu, protože žáci těchto škol mají oproti gymnáziím nižší počet hodin výuky dějepisu daných rámcovými učebními plány a museli o to víc pracovat nad rámec výuky. Jejich výstupy byly $\mathrm{v}$ mnoha prípadech srovnatelné s prací gymnazistů.

Ve výsledku vznikly krásné výstavy zaměřené na různá období a témata $\mathrm{z}$ dějin 20. století. Zapojené školy často vycházely z genia loci svých obcí, což činilo každou jednotlivou výstavu jedinečným odrazem života $\mathrm{v}$ daném místě potažmo regionu.

Velkým pozitivem školních výstav byla také jejich haptická dostupnost, kdy si mohli „osahat dějiny“ i žáci slabozrací a nevidomí, jimž jsou muzejní výstavy a expozice často nedostupné. $\mathrm{V}$ tomto ohledu bych ráda vyzdvihla výstavu žáků osmého ročníku Masarykovy základní školy v Lubenci. Nejen že výstavu připravili, ale také ji představili ostatním spolužákům a veřejnosti během dne, kdy aktivně návštěvníky provázeli, dovolili jim si předměty prohlédnout zblízka a $v$ řadě př́padů si i vyzkoušet jejich funkčnost.

To, že projekty mohou být prospěšné i z hlediska navázání nové nebo prohloubení stávající spolupráce mezi školami, zřizovateli a různými subjekty, dokazuje spolupráce školy s obcí i dalšími partnery, kterou navázaly např. Základní škola v Litomyšli, 22. základní škola v Plzni nebo Základní škola Veltrusy. Tyto školy si vyjednaly možnost vynesení svých školních výstav do veřejného prostoru, což umožnilo jejich zpřístupnění širší veřejnosti bez omezení vázaných na př́stupnost škol.

Ve snaze charakterizovat práci zapojených školních kolektivů lze pozitivně hodnotit další doprovodný program ke školním výstavám, který byl velmi rozmanitý - od komentovaných prohlídek pro spolužáky i veřejnost, přes využití aktivity žáků a zapojení do příprav projektů další vzdělávací obory jako je Český jazyk a literatura, Výchova k občanství / Občanský a společenskovědní základ, Výtvarná výchova, Hudební výchova s přsahem do různých prưrezových témat (Výchova k myšlení $\mathrm{v}$ evropských a globálních souvislostech, Výchova demokratického občana, Osobností a sociální výchova, Mediální výchova a dle charakteru výstav i další průřezová témata). Např. z hlediska Hudební výchovy lze ocenit četné zahájení školních výstav formou slavnostních vernisáží, kdy žáci za korepetice pedagogů nebo vlastního hudebního doprovodu zazpívali písně spojené s historickými mezníky našich dějin. Opakovaně zazněly písně: Ach synku, synku; Bratříčku, zavírej vrátka; Modlitba pro Martu a nechyběla ani česká a slovenská státní hymna. Ojedinělým prvkem byla vlastní autorská píseň bývalé žákyně Základní školy v Litomyšli Kateřiny Mackové, kterou složila přímo pro př́ležitost projektu 100 let Československa v naší škole. 
Ke dni 28. 3. 2018 byli za Českou i Slovenskou republiku vyhlášeni vítězové. Vítězné kolektivy vybírala pětičlenná porota složená z autorů Česko-slovenské / Slovensko-české výstavy z NM a SNM včetně ředitelů obou Historických muzeí, přičemž českou porotu doplnil muzejní pedagog ze SNM a slovenskou porotu muzejní pedagog z NM. K tomuto opatření bylo přikročeno $\mathrm{z}$ důvodu, aby nemohl být nikdo z porotců nařčen ze zaujatosti. Na prvním místě se s výstavou Retro aneb co prarodiče málem vyhodili, připravenou v prostorách dobříšského zámku, umístila kvarta Gymnázia Karla Čapka v Dobříši. Tento prostor si zajistili zcela sami, stejně jako výlepové plochy v obci, aby na svou výstavu upozornili veřejnost. Žákům se podařilo zapojit celé rodiny a vytvořit př́jemné prostředí, kde mohli návštěvníci usednout do křesel, přečíst si knihu, zaposlouchat se do dobové hudby a aktivně využívat vybrané exponáty.

Celou výstavu uvedli žáci slavnostní vernisáží s hudebním programem. Na této vernisáži také zhodnotila vyučující Mgr. Š. Musilová jejich práci, a poděkovala jim za vynaložené úsilí. Následně žáci poděkovali svým rodičům za pomoc a vyučující za motivaci a podporu. Všem dali jako poděkování květinu.

Odměnou všem zúčastněným českým školním kolektivům byla volná vstupenka na lektorovaný program Česko-slovenské I Slovensko-české výstavy v Praze a vítězným školním kolektivům z České a Slovenské republiky pak bylo odměnou dvoudenní setkání v Bratislavě. Zde měli připravený společný program a obdrželi i hodnotné ceny v podobě flash disků, sad versatilek $\mathrm{s}$ barevnými náplněmi, bloků, knih apod. Žáci si vzájemně odprezentovali své zkušenosti s př́pravou výstavy, prohlédli si Slovensko-českou výstavu na Bratislavském hradě, od které se odvíjel soutěžní kvíz, užili si odpoledne s ilustrátorem komiksů a zahráli si akční hru v centru Bratislavy. Velice kvitovaný byl jimi i večerní program, kdy všichni zúčastnění navštívili divadelní hru Dubček v divadle Arena. Př́ijemným zážitkem byla po skončení představení i večerní procházka centrem Bratislavy. Noční město mělo úplně jiné kouzlo než ve dne.

Díky obdržené zpětné vazbě od dobříšských gymnazistů jsme získali reflexi jednotlivých aktivit i programu jako celku. Žáci měli volnou ruku, a tak každý pojal zpětnou vazbu po svém. Někde hodnotili klady a zápory $\mathrm{v}$ bodech, jinde napsali souvislý text.

- „DĚKUJEME! To je určitě proní informace. Projekt mi prripadal skvělý - už na začátku byla velká motivace, že výhra je výlet do Bratislavy. Mít atraktivní cenu je pro soutěz dobré. A rozhodně nás zájezd nezklamal, program byl moc hezký. Nejlepší (a ještě navíc tolik k tématu) bylo rozhodně divadlo, celé představení se svou formou, tím, jak nás všechny zasáhlo. Jsem taky ráda, že jsme si mohli projít výstavu, jen bych chtěla trávit trochu víc času venku. Druhý den jsme procházeli Bratislavu, ale klidně bych udělala společnou procházku delší. Ubytování i jídlo byly zařízené výborně, krátká cesta a obědy v restauracích rozhodně na spokojenosti jen prídaly. Těším se, až si výstavu projdeme i v Praze, a taky děkuji všem, kteř́ pro nás připravovali kvíz, komiksy, pracovní listy, a kdo s námi trávili čas a usmívali se na nás."

- "Celkově se mi líbil nápad spojit Čechy se Slováky dohromady."

- "Chtěla bych poděkovat za úžasný nápad - vytvoření takové velké akce, do které se s radostí zapojila spousta škol. Moc mě bavilo celkové tooření výstavy, ale ted' něco $k$ Bratislavě. Už to, že jste nám zařídili dobrý autobus a milého řidiče mě dost potěšilo. Když jsme prijieli do hotelu, mile mě překvapili zaměstnanci, a i hotel se mi líbil. Všichni lidi na nás byli opravdu moc př́iemní. Výstava byla zajímavá a ty interaktioní tabule - výborný nápad. Oběd $v$ restauraci byl výborný, jen by bylo fajn, kdybychom prriššě neměli třikrát po sobě americké brambory a maso. Ty skupinové práce byly zajímavý nápad, ale nějak moc mě to nebavilo. Ale divadlo bylo naprosto úžasné, opravdu jsem si ho užila. Zase jsem se dozvěděla spoustu věcí. 
Hra po městě byla taky skvělá. Měli jsme možnost se něco dozvědět o starém města a mají tam výbornou zmrzlinu."

- „Děkujeme za skvělý výlet do Bratislavy. Netušila jsem, že si se slovenskými dětmi budeme tak rozumět. I když jsme spolu byli jen 2 dny, tak jsme se dokázali seznámit. Výstava je také moc pěkná, některé věci má babička ještě doma. Jediné, co bych asi vytkla je jídlo. Program byl plně nabitý. Velké plus je divadlo, které se opravdu povedlo."

- "Chtěla bych Vám moc poděkovat za krásné zážitky a skvělou atmosféru. Moc se mi zamlouvala výstava. Celý program byl skvěle naplánovaný a naučný. Moc si vážime, že se snažíte spojovat spolu znovu blizké národy."

- "Akce byla skvělá, spousty činností, které bych možná jen rozdělila do více dnu. Úžasný personál, tak pozitioní akční a př́ijemný přistup jsem na žádném výletě asi ještě nezažila."

- "Rozhodně bych byl radši, kdybychom měli trochu volnější program a na vycházkách pauzy na rozchod."

Mezi zápory žáci řadili opakovaně požadavek na více volného času, touhu po větší propojenosti se slovenskými protějšky a pestřejší výběr jídla, který byl způsoben stravováním $\mathrm{v}$ různých restauračních zařízeních, a tudíž nebyl vzájemně koordinován jídelníček, a častější svačiny. $\mathrm{V}$ několika případech také žáci vytkli nedostatek programu $\mathrm{v}$ časových prodlevách, které nebyly vyplněny žádným programem. Jednalo se zejména o prostoje způsobené prostorem pro odskočení si na toaletu, rozdání cen, rozdání a snězení svačin, př́ípadně příprava náročnějších aktivit programu.

Abychom neevaluovali jen dvoudenní bratislavský seminář, připravili jsme a rozeslali zúčastněným školám zpětnovazební dotazníky. Nazpět se vrátily odpovědi od 10 pedagogů a 166 žáků ZŠ, SŠ a SOŠ. Ve všech př́padech vzešla motivace zapojit se do projektu od pedagogů. Ti také hodnotili projekt jako zajímavý a zároveň náročný. Byt' připouští, že náročnost projektu závisí na jeho individuálním pojetí a šíri záběru, k jakým se každý jednotlivý školní kolektiv uchýlí. Přesto většina pedagogů odpověděla, že projekt výrazně převyšoval časovou dotaci danou danému předmětu rámcovými učebními plány, což vyžadovalo větší motivaci žáků. V několika př́padech využívali pedagogové mezipředmětových vztahů, ve dvou případech dokonce nebyl pro prípravu projektu stěžejní předmět dějepis, ale jednalo se o český jazyk a výchovu k občanství.

Jako pozitiva projektu hodnotili učitelé zvýšený zájem žáků a jejich motivaci, která souvisí s jejich zvýšenou aktivitou a rozvojem vzájemné spolupráce. Dále kladně hodnotí, že nastavení projektu umožňovalo zažít úspěch i slabším žákům, kdy si každý mohl najít takovou aktivitu, která ho baví, a prrispět tak $\mathrm{k}$ výsledku celku. Dalším pozitivem s ohledem na žáka je ze strany učitelů vnímána hmatatelnost výsledku, rozvoj kreativity žáků volností pojetí práce a posílení vztahů ve třídě. Z hlediska výuky kvitovali návaznost projektu na RVP, mezipředmětové vztahy, možnost jiného pojetí výuky formou, která je pro žáky snáze uchopitelná s dlouhodobějším dopadem, a př́ležitost pro výuku regionálních dějin. Další vysoce hodnocenou kategorií, která byla jedním z hlavních důvodů, proč se projektu zúčastnili, bylo jeho postavení na principu mezigeneračních rozhovorů, které, jak sami učitelé uvádí, přispěly $\mathrm{k}$ hlubšímu poznání svých rodičů a prarodičů, dále vedly $k$ většímu zájmu veřejnosti a pozitivnímu přijetí.

Jako negativa vnímali dotazovaní učitelé časovou a organizační náročnost projektu, která vyžadovala práci nad rámec výuky nejen pro jejich žáky, ale také pro ně. Objevoval se také názor, že by si úkol takového rozsahu zasloužil větší propagaci.

O projektu se dozvěděli ve většině př́ípadů ze zaslaného e-mailu, ve dvou prŕípadech ze sociálních sítí a webových stránek NM. Osm z deseti respondentů se vyjádřilo, že se projektů zúčastňují pravidelně, zbylí dva jen zrrídka. Z hlediska žáků 
považují projekt za přiměřeně náročný. Ve většině prŕípadů pro ně byl zajímavým zpestřením výuky, dále pak nosným konceptem pro odučení tématu a aktivitou nad rámec výuky. V metodice byl uveden odhad časové náročnosti na 10 vyučovacích jednotek. Šest respondentů uvedlo, že to byl čas odpovídající, čtyři, že tento odhad nebyl dostačující. Zároveň však opakovaně uvedli, že záleží ryze na pojetí projektu.

Zpětná vazba žáků $\mathrm{v}$ mnohém korespondovala $\mathrm{s}$ názory jejich pedagogů. Většina dotazovaných žákư ${ }^{5}$ hodnotila projekt jako snadný až přiměřený, jen $9 \%$ respondentů odpovědělo, že pro ně byl projekt náročný. Jednalo se o žáky ZŠ. Všechny respondenty bez výjimky tento způsob výuky bavil a jen $4 \%$ dotazovaných uvedlo, že by se projektu znovu již nezúčastnili. Ve většině prŕípadů se jednalo o žáky 9. ročníků, kteří se připravovali na přijímací zkoušky na střední školy a práce nad rámec školní výuky pro ně představovala zátěž.

Z hlediska toho, jaká část práce žáky bavila nejvíce, nebyly rozdíly nijak výrazné. Dle výsledku hodnocení lze odstupňovat oblibu typů aktivit sestupně: rozhovory v rodinách; představení školní výstavy spolužákům, rodičům, př́ipadně veřejnosti; příprava školní výstavy a shromaždiování předmětů pro školní výstavy.

Žáci obdrželi čtyři otevřené otázky, které se týkaly toho, na co nejraději vzpomínají, co se dozvěděli nového o své rodině a co jim projekt dal a vzal. Zde byly odpovědi velice pestré. Nejraději žáci vzpomínají na rozhovory $\mathrm{v}$ rodinách, přípravu výstavy, vernisáž a to, jak se výstava návštěvníkům líbila, na čas strávený se spolužáky a vzájemnou spolupráci, na zábavu/ dobrou atmosféru, která při práci vládla, na odkrývání informací $\mathrm{k}$ jednotlivým předmětům. Z odpovědí žáků vyplývá, že projekt neměl jen význam pro seznámení se s moderními dějinami, ale důležitý byl i jeho pozitivní dopad na sociální klima trrídy nebo zkušenost $s$ tvorbou výstavy, tedy komplexního výstupu velkého rozsahu. Díky několika odpovědím, ze kterých vyplynulo, že žáci vzpomínají na př́tomnost koordinátorky projektu na vernisáži výstavy nebo na výstavě samé, se potvrzuje, že je aktivní účast koordinátorů podobných projektů pro zúčastněné žáky důležitá, stejně tak jako jejich zpětná vazba. Cítí tak, že má instituce pořádající soutěž o jejich práci skutečný zájem. Některé z odpovědí byly opravdu působivé: „Děda mi napsal asi 8 stránek sešitu tohoto projektu. Když mi to ukázal, tak jsem se udivil a ptal jsem se, jak dlouho to psal? Řekl mi: "Celou noc jsem kvoili tomu nespal, ale bavilo mé zavzpomínat na staré časy."“; "Nějak jsem se o ty roky nezajímala, ale najednou mi to príšlo zajímavé." Jedna žákyně se podělila o svůj nejsilnější zážitek, když vzpomínala: „Na poslední den príprav před vernisáží. Snažili jsme se doladit poslední podrobnosti, leštili vitríny a $k$ tomu si pouštěli Karla Gotta." Dále namátkou z mnohých odpovědí.

Dozvěděl/a jsem se:

- „že většina členů rodiny něco sbírala (třeba známky)"

- „že moje babička létala s větroněm"

- „že můj praděda byl v 2. světové válce nucen nastoupit bud' do německé armády, nebo koncentračního tábora"

- „zajímavé informace o životě rodičů, jaké měli dětství

- ",ačkoliv jsem se nedozvěděla o rodině jako celku, tak jsem mohla nahlédnout do pestré minulosti mé babičky, kterou jsem neměla možnost nikdy poznat. Zaujala mě jako osoba, babička, matka i jako celnička na hranicích. Vždy mě tato osoba zajímala, je to takové malé tajemství naší rodiny"

- „o životě v Československu, jak se dřív žilo"

- „že dř́ve nebyla taková technika jako je ted', takže to je pro mě nepredstavitelné"

- „že neméli televizi až do roku 1969.“

Z hlediska přínosu projektu byly odpovědi také velmi rozmanité. Všeobecně na otázku "co vám projekt dal" žáci odpovídali: 


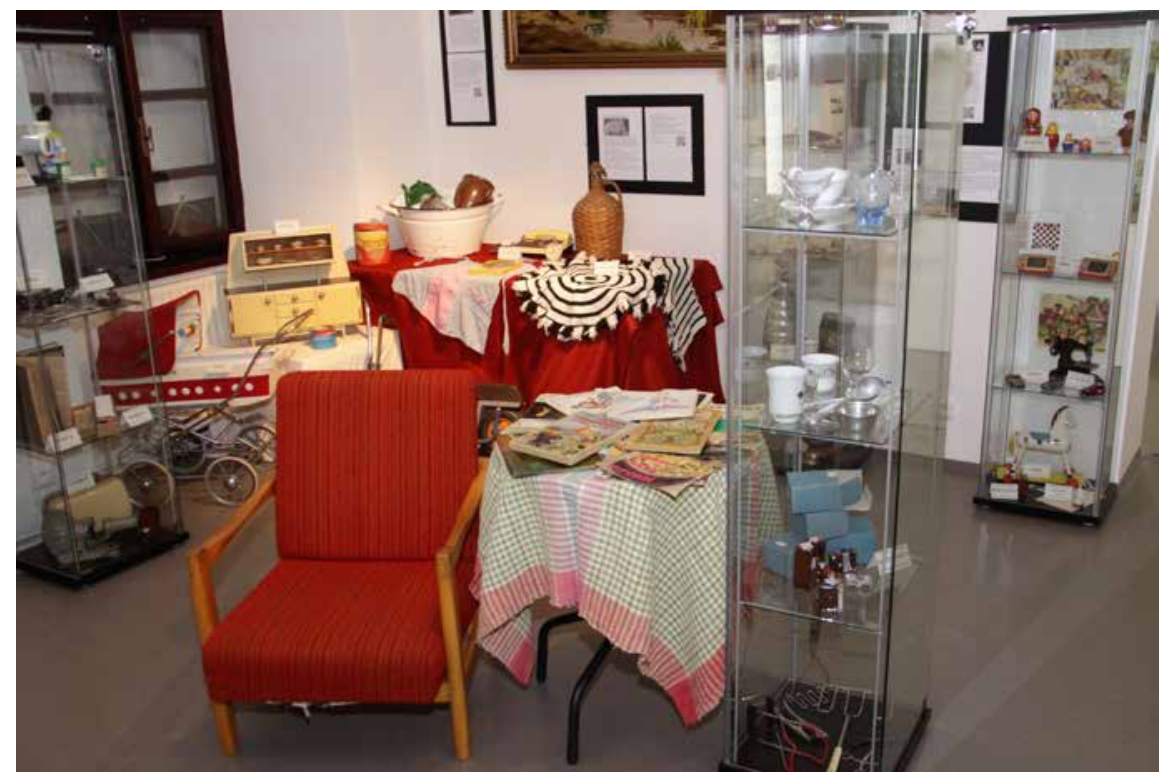

Část výstavy žáků kvarty Gymnázia Karla Čapka v Dobríši, Muzeum Dobřišs, 11. 1. 2018 (foto Š. Musilová) zkušenosti; nové znalosti/poznatky/informace; zážitek; pobavení; bližší vztahy se spolužáky; informace o rodinách mých spolužáků; zjištění, že když se jako třída rozhodneme, tak jsme schopni udělat nádhernou výstavu; další krásné chvíle strávené s babičkou/dědou; vzpomínky; zlepšení ve psaní slohové práce.

Mezi specifické odpovědi patřilo:

- "projekt mi dal možnost prohlédnout si předměty spolužákü, které doma nemáme"

- „informace o každodennosti v Československu"

- "dobré chvíle strávené s rodinou"
- "motivaci zjištovat více o rodině"

- "hezké choíle s tátou“.

Budeme-li se ptát, co jim projekt vzal, dozvíme se, že čas, avšak velmi často s dovětkem, že: "moc rád/a; ale nevadilo mi to; ale nelituji toho, protože mě to bavilo". Případně "nic mi nevzal, dělal jsem to rád". Jednou z četných odpovědí bylo také "nic".

Závěrem dotazníku byla otázka umožňující respondentům doplnit cokoli, co je napadne. V mnoha ohledech se sešly zajímavé odpovědi, které nám poskytují dobrou zpětnou vazbu.

- "Měla jsem hezký pocit z toho, jak byli lidi št’astní z naší práce."

- „Projekt byl velmi poučný a zábavný. Velmi se mi líbilo nadšení všech z výstavy. Náš sborník nadchl mnoho lidí a ocenili naši práci. Myslím si, že mé pocity z výstavy se nedají popsat. Bylo to neuvěritelné."

- "Obdivuji pana učitele, že se do toho s obrovskou radostí zapojil."

- „Díky tomuto projektu napadlo dědu, že se s ním a mojí sestřenkou budeme scházet a on nám bude povídat o životě a my se ho ptát."

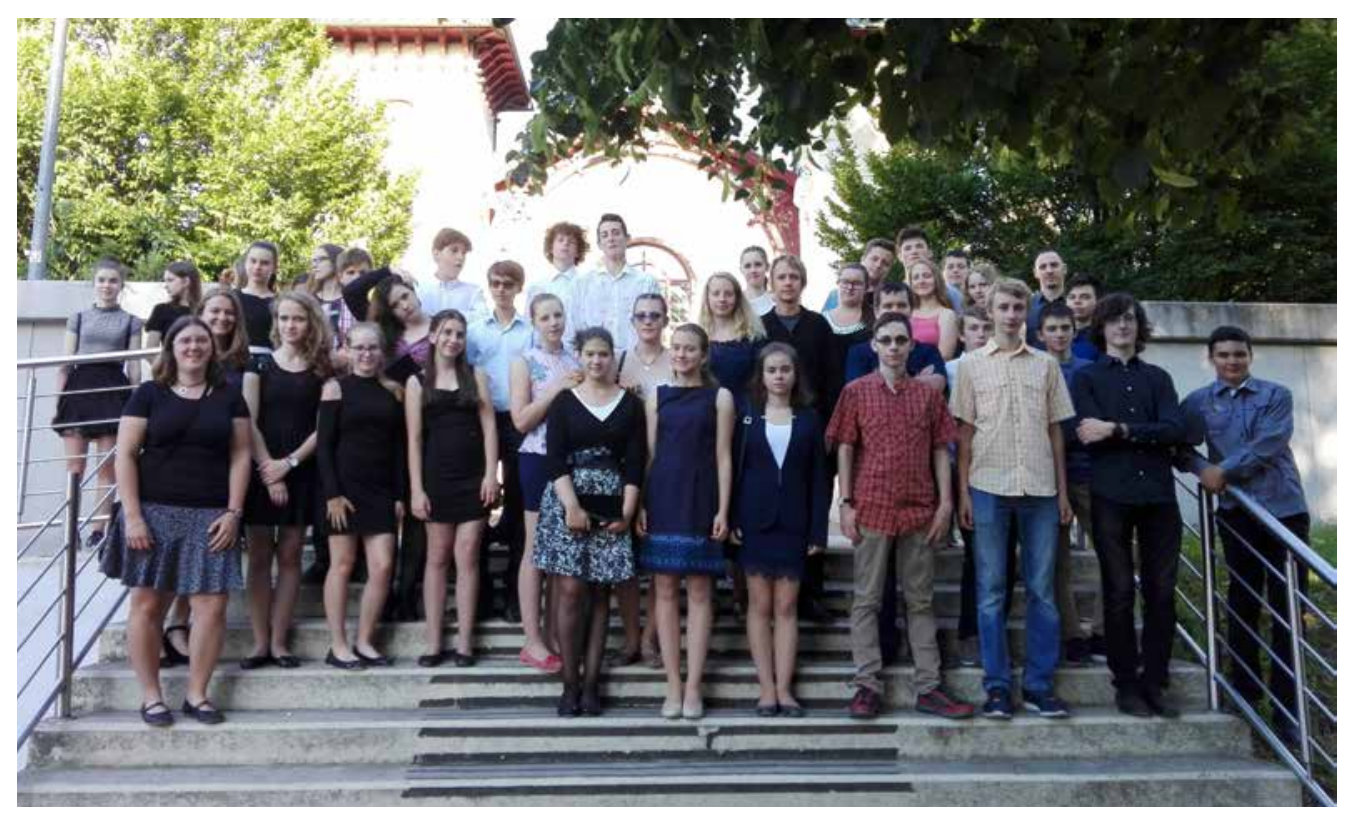

Společná fotografie žáků Gymnázia Karla Čapka v Dobříši a Gymnázia Malacky před predstavením Dubček v Divadle Arena, Bratislava, 19. 6. 2018 (foto Z. Kulhavá) 
- „Myslím si, že je to skvělý způsob, jak žáky zaujmout a více jim představit a přibližit život v Československu."

- "Projekt byl př́jemným překvapením výuky HIS." (pozn. Historického semináře)

- "Tento projekt mé bavil, a i když to bylo náročné, tak se mi to líbilo."

- „Bylo hezké, že se zapojila většina třídy a všichni se opravdu snažili."

- „Kdybych neměla přijímačky, tak bych se zapojila znovu, ale v tomto období to pro mě nebylo zrovna vhodné. Ale na to, že paní učitelku máme jen na dějepis (2x týdně), tak jsem překvapená, jak dobře jsme výstavu zoládli. Jen škoda, že kouili projektu nebudeme podrobně probírat 2. světovou válku."

\section{Interaktivity ve výstavě a samoob- služné pracovní listy}

Tak jako jiná světová muzea, i Národní muzeum si uvědomuje zájem veřejnosti se nejen něco dozvědět, ale také něco zažít a pobavit se. $Z$ toho důvodu byly průběžně ve výstavě rozmístěny interaktivní samoobslužné prvky. Některé měly přispět ke správnému porozumění, jiné měly ryze relaxační charakter. Jejich zaměření bylo také různé - od jednoduchých puzzle,

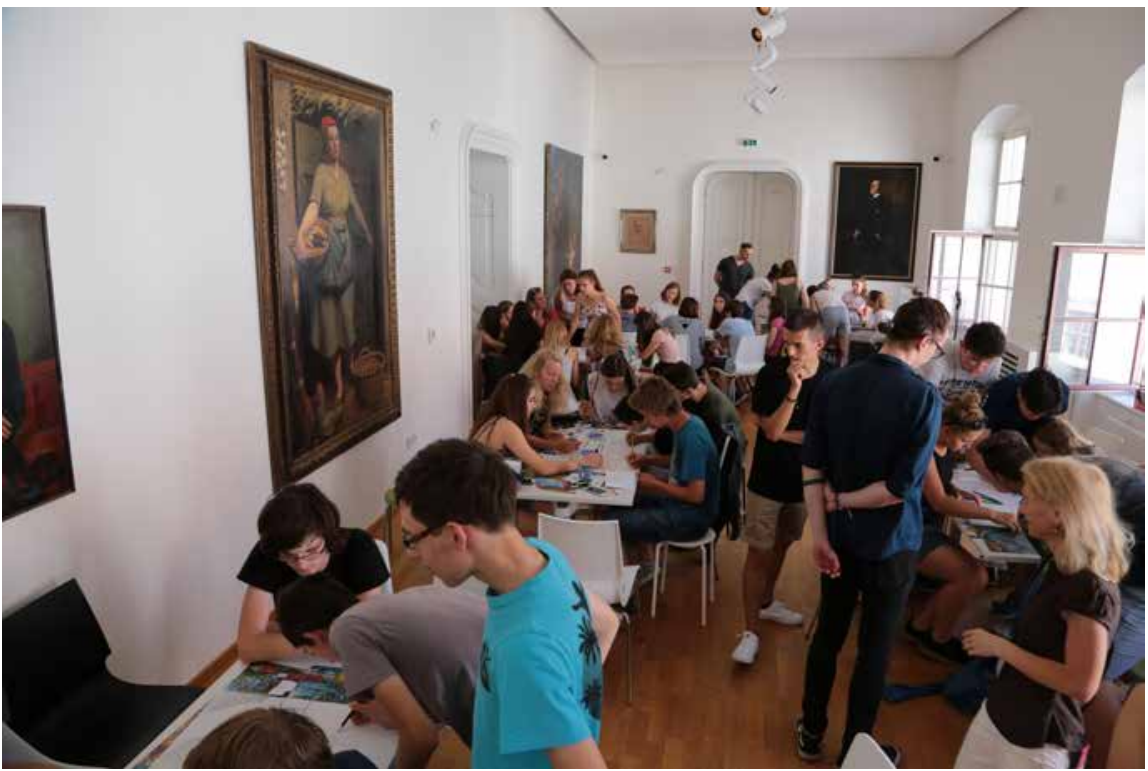

po srovnávání vojenských hodností ve třech historických epochách 20. století. Jednotlivé prvky byly vytvořeny tak, aby byly vícevrstvé a nejmenší návštěvníci si na nich něco mohli vyzkoušet, prohlédnout, osahat, očichat, pohrát si, starší získat potřebnou informaci, porozumět historickým proměnám vybraných fenoménů jako byl 1. máj nebo sokolský slet a spartakiáda apod. Herní prvky pro děti byly svou zábavností atraktivní i pro dospělé návštěvníky.

Jednotlivé interaktivity byly umístěny do zásuvek, které byly součástí výstavního mobiliáře. To bylo pro jejich pojetí značně limitující. Několik z nich, jako např. školní nástěnka, hrací kostky nebo stan „áčko" se nám podařilo vynést do prostoru.

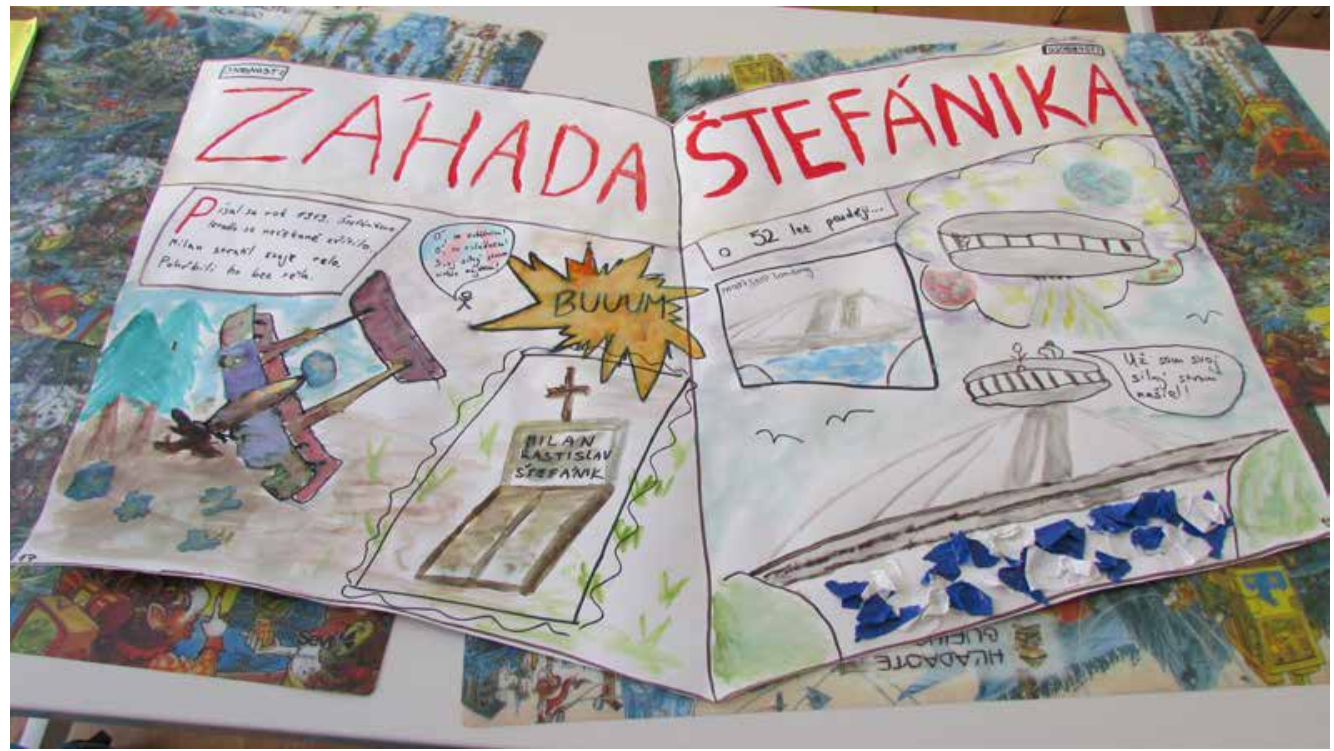

Jeden z vytvořených komiksů, Bratislavský hrad, 19. 6. 2018 (foto Z. Kulhavá) 
Pro zatraktivnění prohlídky návštěvníkům jsme také připravili samoobslužného interaktivního průvodce, který svým zaměřením cílil na návštěvníky staršího školního věku a studenty středních škol. Zaujmout mohl však rozhodně i dospělé. Tento průvodce vedl návštěvníky jednotlivými tématy výstavy, v nichž upozorňoval na zajímavé exponáty nebo fakta. Využíval samoobslužných interaktivních prvků nebo informací v elektronických infokioscích, které byly ve výstavě rozmístěné. Nadstavbou pak byly doporučené
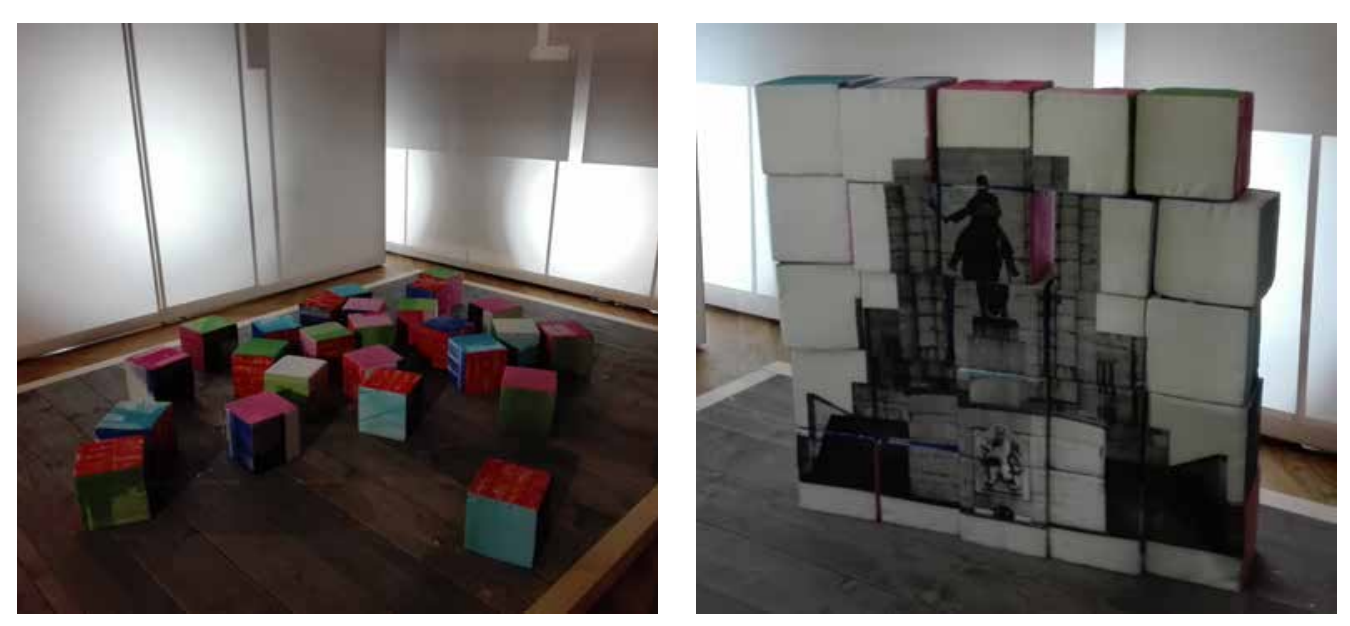

Stavebnice z molitanových kostek, na jejichž jednotlivých stranách bylo vyobrazeno šest významných českých a slovenských staveb. Pro děti zábava, pro starší návštěvníky relaxace (foto Z. Kulhavá) vit pro ně zajímavý program. Využít lze cokoliv a nezávisí to nutně na finančním rozpočtu. Samozrejmě nelze opomenout, že když máte k dispozici rozpočet na větší akci, jako je např. dvoudenní exkurze pro 30 žáků a pedagogický doprovod v Bratislavě, je to obrovský benefit, který přidá daným aktivitám na atraktivitě.

U projektů je ovšem potřeba zvážit přínosy i rizika. Jsou náročné na přípravu, a když se podaří, mají pro cílovou skupinu velmi pozitivní a dalekosáhlý dopad. Rizikem projektů takového rozsahu může být nezájem škol pouštět se do velkých akcí nebo jejich nepřipravenost, která zájemce o účast odradí již v jejich počátku nebo průběhu. Proto je nepostradatelná role autora a koordinátora projektu, který

filmy, které se daným tématům věnují, at’ už umělecké nebo dokumentární. Film je fenoménem 20. století a náměty ke zhlédnutí vybraných snímků dnes mohou být pro žáky/návštěvníky plnohodnotnou součástí vzdělání, stejně jako literatura.

\section{Závèr}

Jak vyplývá z textu, muzea a pamětové instituce celkově, mají mnoho nástrojů, jak různá témata výstav zprostředkovat svým návštěvníkům, oslovit co nejširší spektrum možných cílových skupin a připra-

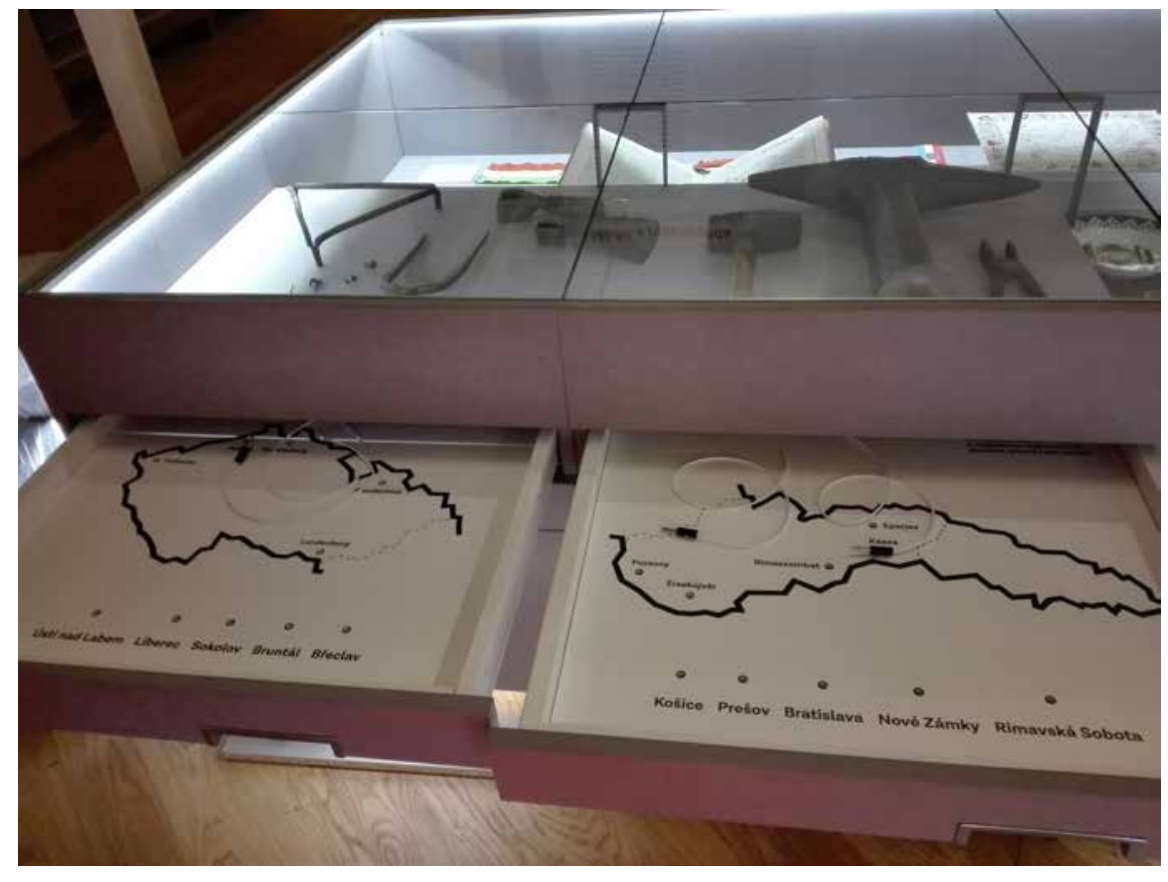

Elektronická spojovačka, jejímž prostřednictvím se návštěvníci seznamovali s německými názvy českých a mad'arskými názvy slovenských měst, 2018 (foto Z. Kulhavá)

Zásuvky s interaktivitami byly označeny zelenou barvou. Odlišovaly se tak od ostatních zásuvek, které ve výstavě ukrývaly další sbírkové předměty nebo doplňková témata. 
aktivně komunikuje s pedagogy i žáky, projevuje zájem o jejich práci a účastní se prezentace výstupů jejich aktivit.

Důležitou součástí práce se školami je průběžné rozšiřování sítě kontaktů na pedagogy škol všech stupňů a typů. To se netýká jen projektů jako 100 let Československa v naší škole, ale také edukačních programů, besed s pamětníky a dalších doprovodných programů určených této cílové skupině.

Jak jeden $\mathrm{z}$ dotazovaných pedagogů $\mathrm{v}$ dotazníkovém šetření uvedl, projekt by si zasloužil větší propagaci. To platí pro doprovodný program a další aktivity muzea všeobecně. A netýká se to jen Národního muzea. $\mathrm{V}$ současné době potřebujeme také cílit čím dál tím více na virální návštěvníky, kteří navštěvují muzea pasivně skrze jejich webové stránky a aplikace. $\mathrm{Z}$ hlediska vzdělávání a předávání kulturních hodnot společnosti jsou aplikace zajímavým zpestřením, ale nic nenahradí onoho genia loci pamětových institucí a opravdový zážitek, který jim může poskytnout autentický předmět.

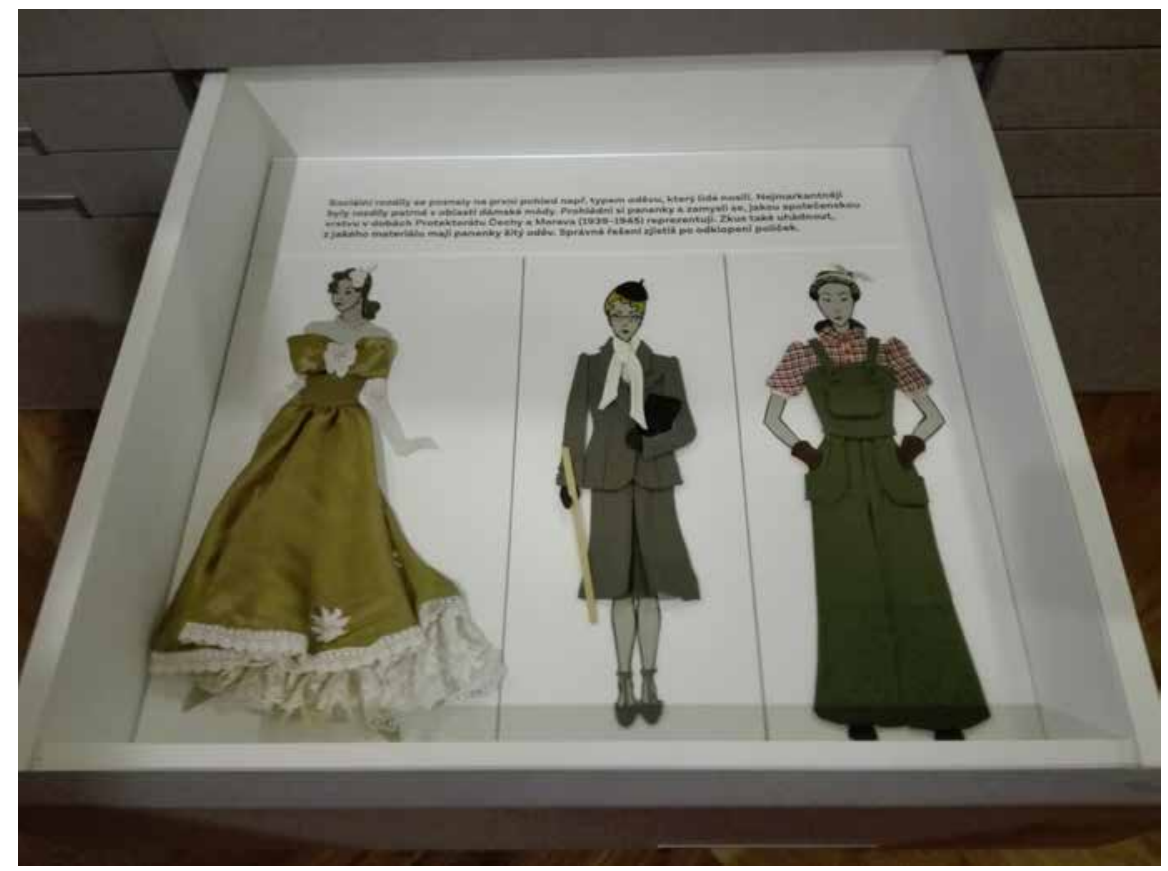

Stejně tak hodnotíme stále jako smysluplné tištěné doprovodné materiály $\mathrm{k}$ výstavám a expozicím - orientační plánky, pracovní listy, interaktivní průvodce apod. Kapacity edukačních programů v dnešní době nestačí reflektovat poptávku, a tak považujeme za důležité dát školám a veřjejnosti šanci projít si výstavu a odnést si z ní zážitek umocněný právě prací s doprovodným materiálem.

Dnes stále populárnější interaktivní prvky ve výstavě také nabývají na významu. Už

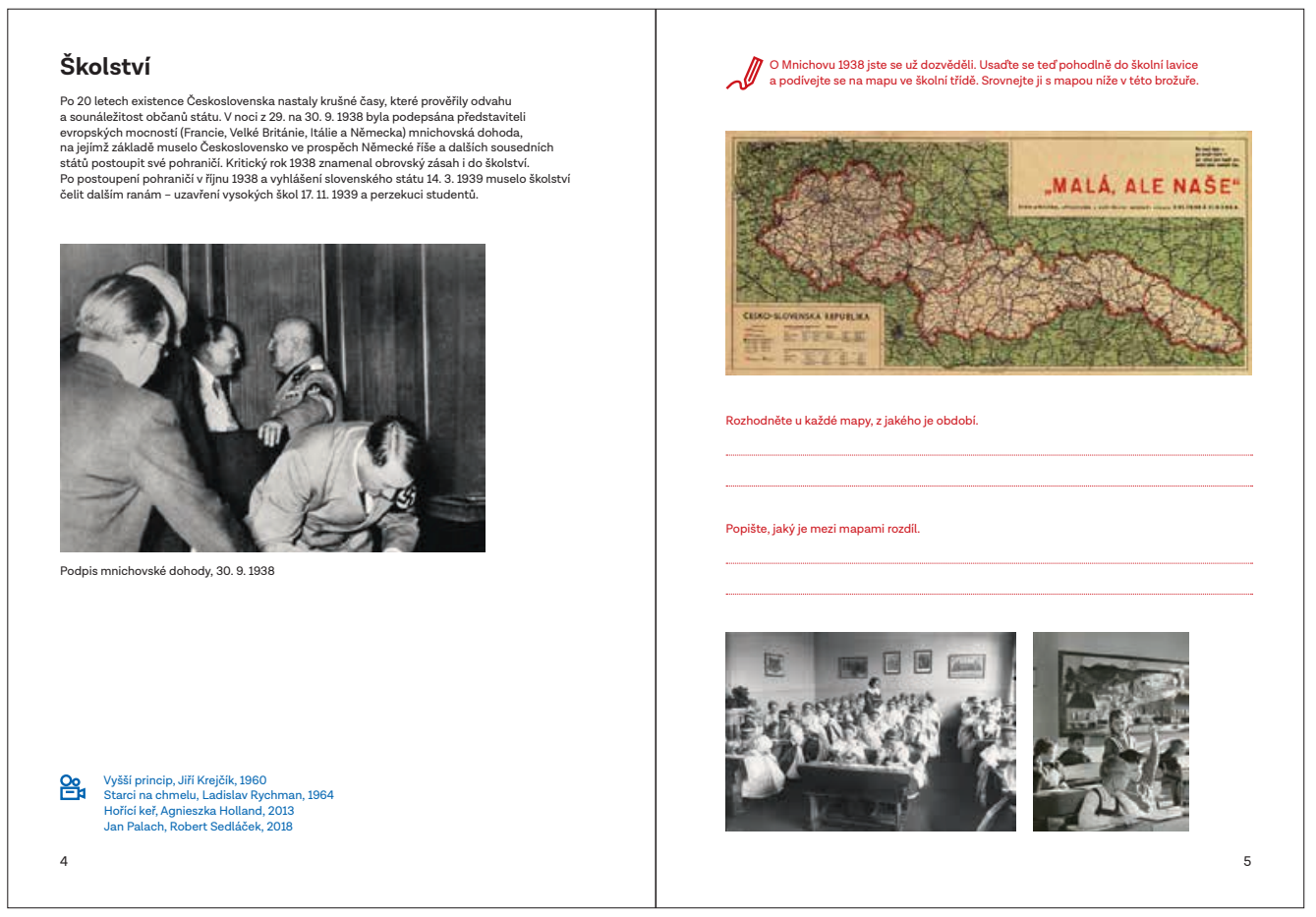

Dvoustrana samoobslužného interaktivního průvodce výstavou, 2018 (Národní muzeum) 
se nejedná jen o samoúčelná "hýblátka“, jak jsou někdy hovorově označovány dotykové obrazovky umožňující prohlížení fotek nebo videí. Návštěvníci chtějí víc. Pracovníci oddělení vzdělávání a kulturních aktivit NM si kladou za cíl, a v případě Česko-slovenské / Slovensko-české výstavy tomu nebylo jinak, vytvářet interaktivity s vícevrstevným obsahem, které si oblíbí návštěvníci všech věkových skupin. Zároveň u výstav takového rozsahu, jako byla tato, je nutné zohlednit, aby interaktivní prvky necílily jen na osvojování si nových znalostí nebo řešení složitých rébusů a situací, ale naopak, aby daly návštěvníkům možnost uvolnit se, zregenerovat svou mysl, která pak o to lépe bude vstřebávat další informace a koncentrovat se na odbornou složku výstavy.
Edukace je ve světových muzeích považována za naprosto běžnou součást nabídky a je respektována a podporovaná např́íc těmito institucemi, at' už se jedná o edukátory nebo o odborné pracovníky. Všichni si jsou rovni a všichni se snaží, aby vizitka muzea byla co nejlepší, aby se zde návštěvníci bavili a rádi se vraceli zpět.

Česko-slovenskou / Slovensko-českou výstavou jsme si nepřipomněli jen 100 let založení Československé republiky, ale také jsme si mohli na různých aktivitách ríci, co pro nás návštěvník znamená a co od nás očekává. $V$ přípravě nových expozic jsou tyto zkušenosti k nezaplacení a jistě budou zúročeny. 